\title{
The Role of Employee Engagement in Work-related Outcomes
}

\author{
Faisal Hanif $^{1, *}$, Sayyed Muhammad Mehdi Raza Naqvi ${ }^{1}$, Karar Hussain ${ }^{2}$ \\ ${ }^{1}$ Muhammad Ali Jinnah University, Pakistan \\ ${ }^{2}$ COMSATS Institute of Information Technology, Pakistan
}

Copyright $(\subset 2015$ by authors, all rights reserved. Authors agree that this article remains permanently open access under the terms of the Creative Commons Attribution License 4.0 International License

\begin{abstract}
Competitive environment provides an opportunity to grow for banks. Whereas in Pakistan banks are unable to create work engagement environment which, results in low job satisfaction and organizational commitment. The aim of this study was to investigate the determinants of employee engagement in Pakistan's banking sector. A self-administered questionnaire was used to collect data from banking sector employees. The results clearly indicate that core self-evaluation and service environment of organization are positively and significantly related with employee engagement. This indicates the optimism of the employees which reflects that they invest more power, energy and engage their selves in the best way to utilize resources and time on work floor.
\end{abstract}

Keywords Self-evaluation, Services Environment, Employee Engagement, Organization Commitment, Strategies

\section{Introduction}

Today organizations are facing business environment change but at the same time they are striving for excellence raising the bar of completion. In this competitive situation, employees' engagement has increasingly engaged the interest of academics and practitioners. Many researchers consider employee engagement as an essential element for human recourse practices because it is human recourse through which businesses can cope with uncertainties in business conditions [1]. Employees are supposed to be confident, cooperative and flexible. Organizations demand professional attitude, behavior and best performance from their employees [2]. Employees' engagement is reflected in satisfaction or feeling of employees and his actual behavior [3].Such satisfaction is the outcome when employees are psychologically willing to be committed for organizational success [4].

The most respected work on engagement was accomplished by Kahn [3; 5] Abstractly, Kahn began with the work of $[6 ; 7]$ who proved that, People's performance will be different in state of engagement or disengagement [3].

Today industrial researches are focused on employees' engagement yet academic researchers are far away from such significant area of research [8; 9]. In Pakistan, banking sector is also neglected especially when it comes to research; limited studies are available on employees' engagement. Employee engagement can be a significant contributing factor in competitive environment. Human Resource Managers are well aware of this significance. Organizations can achieve competitive advantages if managers are able to make their employees exceptional and outstanding.

Competitive environment is a big challenge to bank industry as well as an opportunity to grow. Today banks are unable to create work engagement environment among their employees in Pakistan which resulted in less job satisfaction and less organizational commitment. Consequently, banking sector has become a steppingstone for employees where their stay duration becomes shorter.

As Kahn [3] described the concept, the best engagement can be employed if employees are willing to help and emotionally motivated to cooperate. As a result when attention is increased, people perform better because they are emotionally attached with their job [10]. Emotional attachments are the result when basic needs of employees are fulfilled. Consequently, their job satisfaction and organizational commitment will be improved [11]. Employees are emotionally and mentally engaged when they know that their best performance will be rewarded in term of promotion and benefits [3]. They work hard as they know the expectations of their organizations. Consequently, the level of job satisfaction and organizational commitment will be increased [12]. Employees' engagement will enhance the job's dedication and commitment to their job [12].

Engaged employees are not men of steel- they do get tired but does not take it as a weakness. As engaged employees have strong bindings to their work they don't take their tiredness as a weakness but it give them a sense of achievement. They do have passion for their jobs. 
Employees' engagement is directly proportional to organizational performance. Similarly, organization is totally dependent on employees because human resources are the core capital of business activities $[12 ; 13]$

The employee engagement is a vast concept but the pivotal objective is to scrutinize the determinants and outcomes of the employee engagement in the banking sector of Pakistan. The precise purpose of this research is also comprised; (a) keeping an eye on empirically test, a theoretical relationship of the antecedents of employee engagement and especially in the banking sector of Pakistan. (b) And to examine the factor leading to engagement (c) to confirm the relationship between employee engagement and its outcomes on job satisfaction and organizational commitment, this study will also add handsome literature on the subject.

\section{Literature Review}

\subsection{Employee Engagement}

A review of literature suggests that employee engagement has been conceptualized in three different ways. First Kahns provide the theoretical base of employee engagement [14; 15]; Engaged employee denotes their energy toward organizational goals [16]. In contrast, [3] the disengagement is defined as "the uncoupling of selves from work roles" [3,p. 694] and disengaged employee physically and mentally uninvolved in the job they conceal their feelings and their relations with manager and with other employees.

The second notion of engagement was extended by burnout theorist [17] and [18] who construct the engagement is the opposite of the burnout. The burnout has three dimensions: exhaustion, cynicism, and sense of inefficacy. However, burnout theorist formulated an effective definition of engagement, and these researchers deliberate that that the employee engagement and burnout are fixed on the opposite side of poles, if employee are not engaged then they must have burnout felling $[18 ; 19]$.

[20] Move towards the last school of thought of work engagement to render a diverse view of the work engagement and burnout continuum theory. This school of thought describes the employee engagement as a "positive, fulfilling, work related state of mind that is characterized by vigor, dedication, and absorption" [20 p. 74). At last, the concept of engagement and organizational citizenship behavior (OCB) are not the same [8]. $\mathrm{OCB}$ is the consequence of the employee engagement. Employee Engagement concentrate on employees extra discretionary effort to perform the job from normal work attitude; but, the OCB refers to the volunteer and informal helping behaviors that intend to help Work fellows and the organization [8].

\subsection{Core Self-Evaluations}

Self-determination theory (SDT) is a theory of enthusiasm; the theory motivates the individual employee to capture authority, challenge and improve the relationships and individual well-being [21]. Employee's ambitions can be divided in to intrinsic aspirations and extrinsic aspirations. Intrinsic aspiration such as personal development, social or business relationship and extrinsic aspiration, such as financial success, and favorable public reputation [22].

[23] clarify a sketchy summary of the main points of the concept of core self-evaluations as an individual quality that would describe job satisfaction and other attitudes and behaviors. [24] concord the CSE can be labeled as the pivotal point of evaluations that employees consider about themselves. In consequence a core self-evaluation is a primary theory that employee grasp about their skill, value, competence, aptitude and worth as an employee in their organizational environment [25]. The employees with positive core self-evaluations assess themselves as talented, valuable, and organized. Core self-evaluations also impact on employee appraisals, attitudes, and behaviours in any given situation [26].

The core self-evaluation (CSE) concept is a build of four diverse but unified and interconnected characteristics: one is the Self-esteem, second generalized self-efficacy, third is locus of control, and fourth is the emotional stability [26]. Self-esteem made up of overall self-acceptance, self-liking, and self-respect [27].

The next self-evaluation characteristic i.e. self-efficacy, it enables an individual to work and to perform perfectly in any situation whether it is full of stress or a convenient condition of work. [27] The events that are occurring in the life of an employee play an important role his performance that relates to locus of control which is the third main characteristic of self-evaluation [28]. Emotional stability of an employee leads to better performance. It is the next characteristic. Neuroticism is a negative thing it leads to emotional instability. These are negative emotions that decrease the performance of an employee. If it is high employee is less engage in the work and vice versa. It is one of the dimensions of the Big Five personality model.

Many researchers find the correlation between Core self-evaluations and employee engagement in his studies. [29] study in two Korean banks based on self-esteem, [30] study on self-efficacy and self -esteem and find that those employees feel they are skilled will consider a job friendly and perform yourself in a every time positive behavior in any situations. [31] Researched in Turkish bank on women managers and engagement.

\subsection{Psychological Climate}

The organizational environment determines the performance and attitudes of employees. Managers that do not build trust with in employees and organization formulate disengagement between employees [32]. It indicates that if management within an organization is unreliable, the perception of job security is threatened; we propose that the emotional connect allow employees to remain engaged. [33] 
Suggest that physical and physiological endorse from leadership within an Organization communes to employees that leaders appreciate their performance and organization commitment and concern for the wellbeing of their employees, which creates an optimistic atmosphere in the employees. When employees within an organization have consensus on their perceptions of the work environment, then their individual perceptions as combined be a sign of group-level, organizational climate [33].

Some researchers give importance individuals own perceptions of the work environment not an organization environment $[34 ; 35]$. So, psychological climate is the perception of the workforce about the organization issues, policies, culture, process, and procedures. If employees feel that their environment is safe then their performance is increase and they engaged with their work [36;37].

Job Demands-Resources (JD-R) Model is also theoretical support for engagement research, [3] three psychological condition theory, is also origins in the JD-R model, which assents an affiliation between employee engagement and its determinant psychological climate. The JD-R defines the antecedents of employee engagement. Thus if employees optimistically evaluate of the work environment in which they are performing the job then employees are become committed, motivated and engaged with their work [38] studies on employees and conclude that employees are more engaged and committed to devote themselves in their job when they sensation that their job is recognized and acknowledged by the institution and they have worthy relationships with workfellows and supervisor.

\subsection{Job Satisfaction}

Literature shows that satisfied employees are highly motivated, have good spirits at job, and work more effectively and efficiently [39]. Employees are also more committed to continuous perfection and to excellence [40]. Job satisfaction can be in different ways. A general concept of job satisfaction is how much an employee affection of his job [41]. Although job satisfaction and organizational commitment are closely related but there are significant difference in the concept of the job satisfaction and employee organization commitment. Organization commitment focus on dedication and loyalty of the employee for their organization, and the job satisfaction focus to the work environment [41].

[42] two-factor theory, also famous as the motivation-hygiene theory, considered as a one of the good theories that elaborates the concepts of motivation and job satisfaction. According to [43] now it is of vital importance to know the difference between the satisfaction and dissatisfaction. To understand the difference between them is that there are two different elements in it i.e. motivating and hygiene. If one is not satisfied with his job it does not mean that he is dissatisfied with the job. This theory makes it easy to understand that opposite or rival of satisfaction is not dissatisfaction but no satisfaction. In the same way the opposite of dissatisfaction is not dissatisfaction. As there are always some employees that are not in both conditions or don't have any of the above feelings. Factors that motivate employee may increase his satisfaction int the job but it does not mean that in the absence of these factors employee will be dissatisfied [44].

On the other hand hygiene factors also effect the satisfaction of the employee. In the absence of these hygiene factors it may be a possibility that job dissatisfaction may occur but it is not necessary that having these factors may encourage job satisfaction. Motivating factors are satisfactory; hygienes lead little job satisfaction, but also stop job dissatisfaction [45].

In theory, engagement and satisfaction are separate conceptions, there is confirmation for overlap in the definitions; in particular, affective reactions to the job are present in both definitions [46]. [47] Suggested that when the employee they catch personal meaning and motivation in their work and receive positive response from their supervisor they become more engage in their work.

\section{Organizational Commitment}

[48] Specified organizational commitment as involvement in, feeling of affection and emotional attachment with organization in which employee perform job. More often, [49] defined OC by way of a term that "encompasses an active relationship with the organization such that individuals are willing to give something of themselves in order to contribute to the organization's wellbeing" [49, $p$. 226]. Organizational commitment as a psychological connector with an organization, the previous research literature exposes various patterns of commitment depending on operationalization [50]. Organizational commitment build, one of the leading is [51] who operationalized three aspect of commitment: affective, continuance, and normative commitment. In this research crucial point is affective organization commitment that deals employee personal affection, appreciation with and at the end result the employee perform extra and discretionary role [52].

The JD - R theory and the social exchange theory also define the relationship between employee engagement and organizational commitment. The JD-R theory presumes that job resources facilitate employee's to finish his work perfectly and achieve work goals these resources provide knowledge, learning, and development [53]. The social exchange theory [54] requires repayment; an employee who obtains advantage from employer and in paying back he must provide something valuable. Add together these two theories; employees who receive social as well as economic resources from their organization might have emotion of responsibility to repay the organization in some kind [55].

For the purpose of repayment employee can also repay their organization to increase commitment to the organization. $[56 ; 8]$ have identified a positive relationship between employee engagement and organizational commitment. [57] indicated that engaged employees think the organization has fulfilled their necessary human 
requirements and helped them accomplish their goals through resources like empowerment, helpful co -workers, suitable feedback, training and development, and appraisal from the management, they are feel obligated to the organization; later on, engaged employees are more enthusiastic to devote their efforts to operating organization, an element of organizational commitment [51]. [8] explain in his study that engaged employees and their organization keep up a mutual exchange relationship based on trueness, dedication, and commitment.

[58] advised that employees who are keen to offer his energy to accomplish organizational goals would have a higher affective commitment to the organization. So engaged employees observe similarity between their and organization goal and that's why employee involved to the organization [59]. Engaged employees are concern about their organization future [60]. Recent meta-analysis studies on burnout and engagement is extensively correlated to a number of outcomes including organizational commitment $[61 ; 62]$

\section{Hypotheses}

On the bases of the above research literature and argument the theoretical frame work has been developed which is given in figure 1. The hypotheses that are purposed are these

H1: Core Self-Evaluations has a positive and significant effect on employee engagement.

$\mathrm{H} 2$ : There is a positive and significant relationship between psychological climate and employee engagement.

H3: There is a positive and significant relationship between employee engagement and job satisfaction.

H4: There is a positive and significant relationship between employee engagement and Organization Commitment.

\section{Data and Methodology}

Population and Sample: Banking sector of the Pakistan is the target population of this study. Due to time and financial limits total questionnaire for this study used are 260 workers from banking sector of Pakistan. Convenience sampling technique was used to roll up the data from workers in Pakistani Banking Sector and form different cities (Islamabad, Rawalpindi and Lahore) of Pakistan.

Banking sector is growing far faster than any other sectors in Pakistan. As financial sector is the backbone of any country, banking sector plays an important role to lead the country in economic world. Competition in this sector is growing faster that result into well organized and qualitative services, which well serves the needs of the consumer as well as for country. Overall competition is well satisfying the financial needs of the country.

Data Collection: This research was based on self-reported questionnaire. The final questionnaire was disseminated between the different banks branches in the Pakistan. All questionnaires were personally visit and through emails circulated among the workers and the response rate was very good.

Almost 450 questionnaires were disseminated among the workers. Almost 290 questionnaires were return back for the analysis purpose, out of which 30 questionnaire were discarded due to unfinished responses. The 260 survey form was coded in SPSS for analysis purpose and the response rate was $57 \%$.

Data Processing: The SPSS and AMOS software were used to analyze the data. The specific statistical techniques were used in SPSS and Confirmatory Factor Analysis techniques were used in AMOS. Software is used to run different data analysis techniques to support study hypothesis like descriptive statistics tests, reliability test, and correlation.

Measures: The questionnaires were divided in to two sections. The first portion of the questionnaire based on the respondent demographics and the second label the study related variables

In First part, five demographic questions requested from respondent including; 1) Gender, 2) Age, 3) Marital status, 4) Qualification, and 5) Experience under immediate supervisor.

The second part of the questionnaire were included the questions about variables. [63] 9-item scale adopted. These statements are measure through a Likert scale of 5-points. (1 for strongly disagree to 5 for strongly agree). The core self-evaluation of the respondents adopted [64] 12 items are included in this scale. The psychological climate scale items were adopted from [65]. 13 items are included in psychological climate questionnaire. The job satisfaction scale was consisting of 3 items; adopted from [66] The last part of scale was associated to the organization commitment. 15 items are comprised in this scale and the scale was adopted from [49].

\section{Results and Discussion}

The sample size of the respondents is contains of 260 employees with 210 males $(80 \%)$ that presenting the bulk of the respondents and 50 females (20\%) presentation the lesser of the employees. The largest group of the respondent is around about $200(76 \%)$ is between the age of $20-29$ years, $40(15 \%)$ between the ages set of $30-39,10(3.8 \%)$ mid the age set of 40-49, $10(3.8 \%)$ above the age of 50 .

For nature of job $220(85 \%)$ respondents are salaried on permanent base and $40(15 \%)$ respondents are employed on contract basis.

As reported to the work in the present bank branch 40 (15\%) responder are job experience is less than 1 year, however $147(56 \%)$ are employed from 1-3 years. The respondents $35(13 \%)$ are salaried from 4-6 years, 7-9 years' experience workers are $20(7 \%)$ and $18(6 \%)$ employees have more than 9 years job experience in banking sector. For 
the job designation and position of the respondents $214(82 \%)$ respondents are employed on non-manager level position and $46(18 \%)$ respondents are working on manager level designation.

For responder education The MPhil degree holder employees are $16(10.4 \%)$, and the majority of the employees are master degree holders. The LLB consider as bachelor degree and the ACCA and ACMA two professional degrees are in Pakistan consider as master degree.

Table 1. Descriptive Analysis

\begin{tabular}{ccccc}
\hline Variable & Mean & $\begin{array}{c}\text { Std. } \\
\text { Deviation }\end{array}$ & Skewness & Kurtosis \\
\hline Engagement & 3.8497 & .76745 & -1.029 & 2.224 \\
Evaluation & 3.6865 & .63952 & -.863 & 1.639 \\
Environment & 3.7203 & .78697 & -1.091 & 2.828 \\
Satisfaction & 3.4892 & .83163 & -.280 & -.324 \\
Commitment & 3.5901 & .68726 & -1.079 & 1.759 \\
\hline
\end{tabular}

Table 1 shows the descriptive analysis of the employees of banking sector regarding their engagement in their work. Information of the factors is illuminated by that description.

Mean value and standard deviation (SD) shows that a large number of employees are engaged well in their work.
Table 2. Correlation Analysis

\begin{tabular}{cccccc}
\hline Variable & 1 & 2 & 3 & 4 & 5 \\
\hline Engagement & 1 & & & & \\
Evaluation & $.573^{* *}$ & 1 & & & \\
Environment & $.603^{* *}$ & $.619^{* *}$ & 1 & & \\
Satisfaction & $.429^{* *}$ & $.401^{* *}$ & $.424 * *$ & 1 & \\
Commitment & $.660^{* *}$ & $.578^{* *}$ & $.607^{* *}$ & $.470^{* *}$ & 1 \\
\hline
\end{tabular}

** Significant at the level of 0.001

The values of Skewness and Kurtosis show the normality of the data. As shown in the above table the value of skewness was between -1 and +1 and the value of kurtosis was between -3 and +3 , which assures the normality of the data.

The cronbach alpha shows the reliability of the scale that is used for the study. The employee engagement's coefficient for cronbach alpha is 0.886 , for core self-evaluation is 0.679 , for psychological climate is 0.817 , for job satisfaction it is 0.510 and for organizational commitment is .749. Significant contribution of all questionnaire items to the cronbach alpha coefficient is 0.923. As resulted from the cronbach alpha the internal consistency is relatively high for all the items.

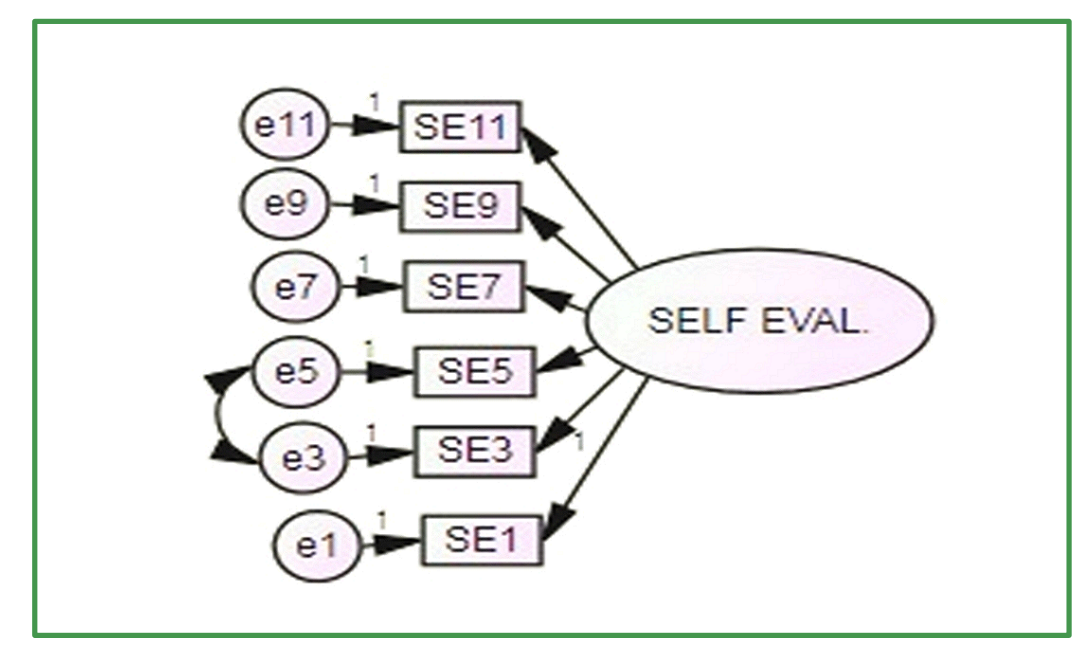

Figure 1. Scale Level Measurement Model of Self Evaluation

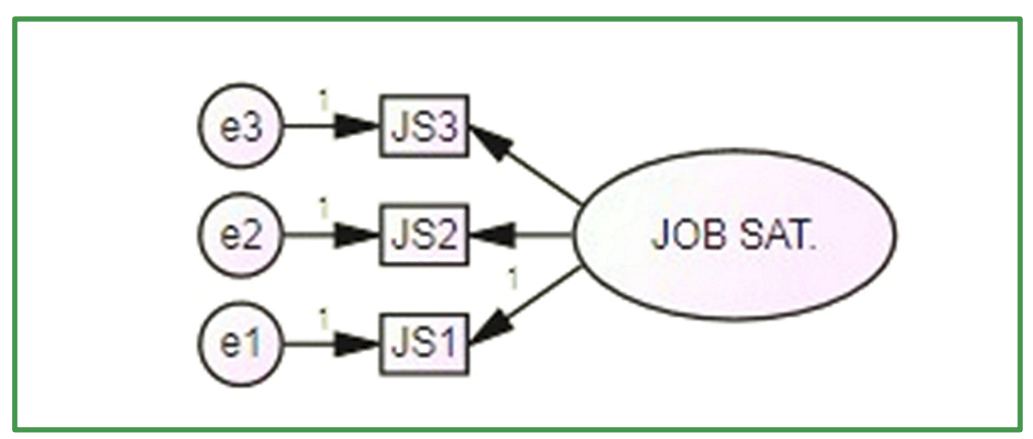

Figure 2. Scale Level Measurement Model of Job Satisfaction 


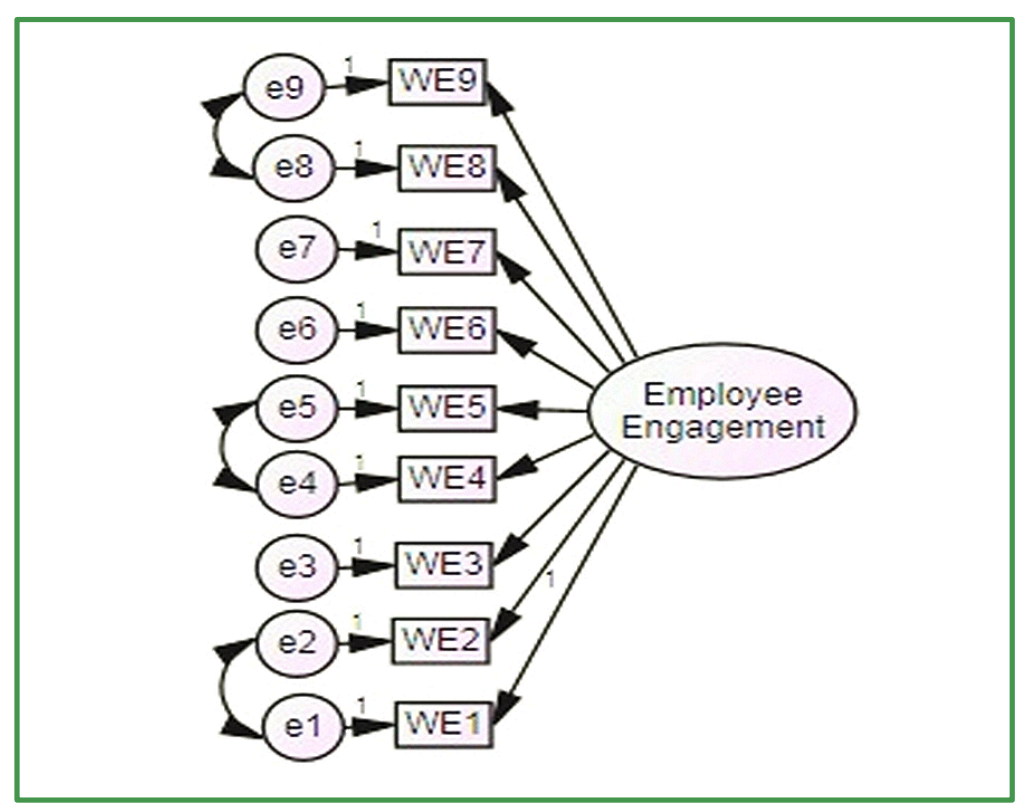

Figure 3. Scale Level Measurement Model of Employee Engagement

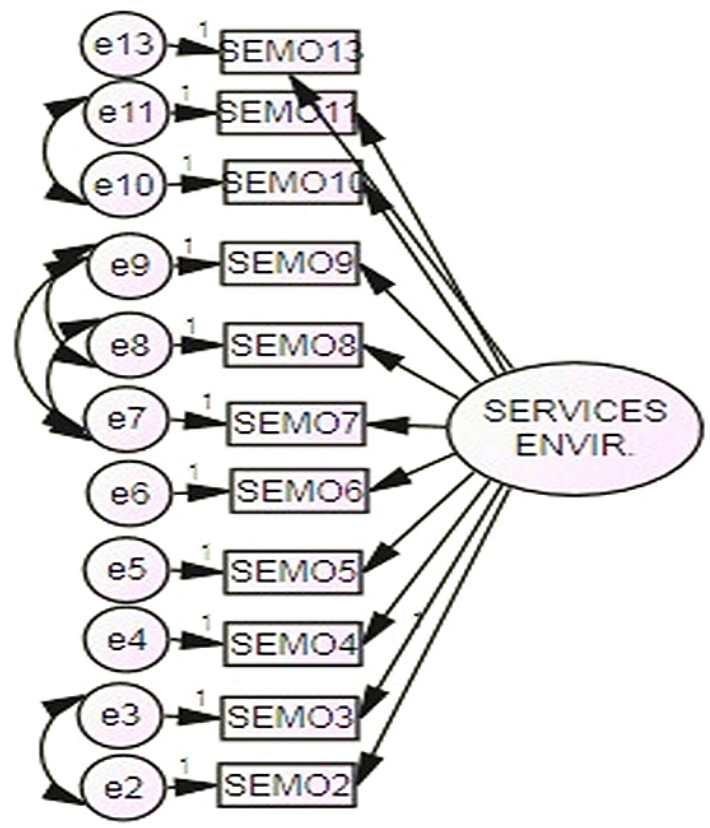

Figure 4. Scale Level Measurement Model of Services Environment 


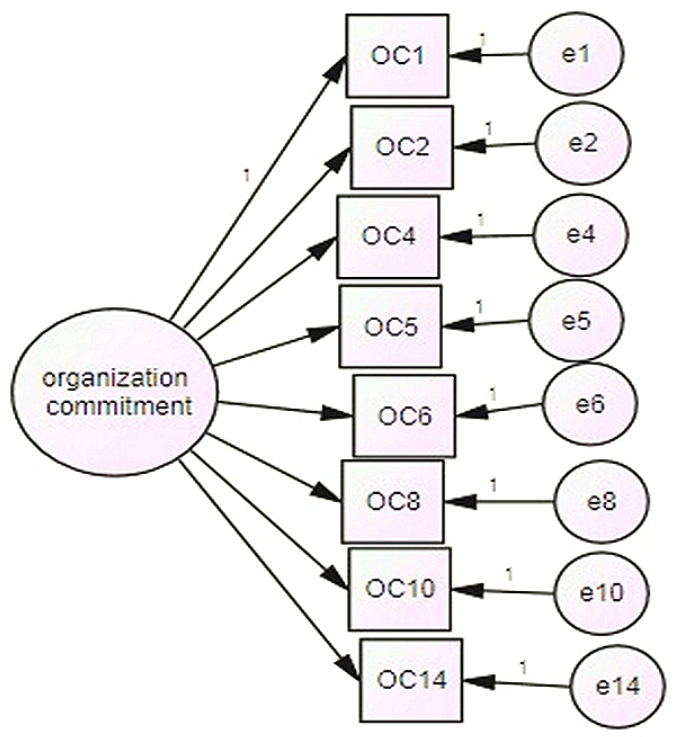

Figure 5. Scale Level Measurement Model of Organization Commitment

Table 3. Model Fitness summary

\begin{tabular}{cccccccc}
\hline Model & CMIN/DF & RMR & GFI & AGFI & PGFI & RMSEA & PCLOSE \\
\hline Employee Engagement & 1.311 & .092 & .959 & .923 & .511 & .045 & .540 \\
Self-Evaluation & .602 & .027 & .990 & .972 & .377 & .000 & .909 \\
$\begin{array}{c}\text { Services Environment of } \\
\text { Organization }\end{array}$ & 1.730 & .057 & .927 & .877 & .548 & .069 & .127 \\
$\quad$ Job Satisfaction & ---- & .000 & 1.000 & ---- & ---- & ---- & ---- \\
Organization Commitment & .626 & .049 & .988 & .964 & .544 & .000 & 0.985 \\
\hline
\end{tabular}

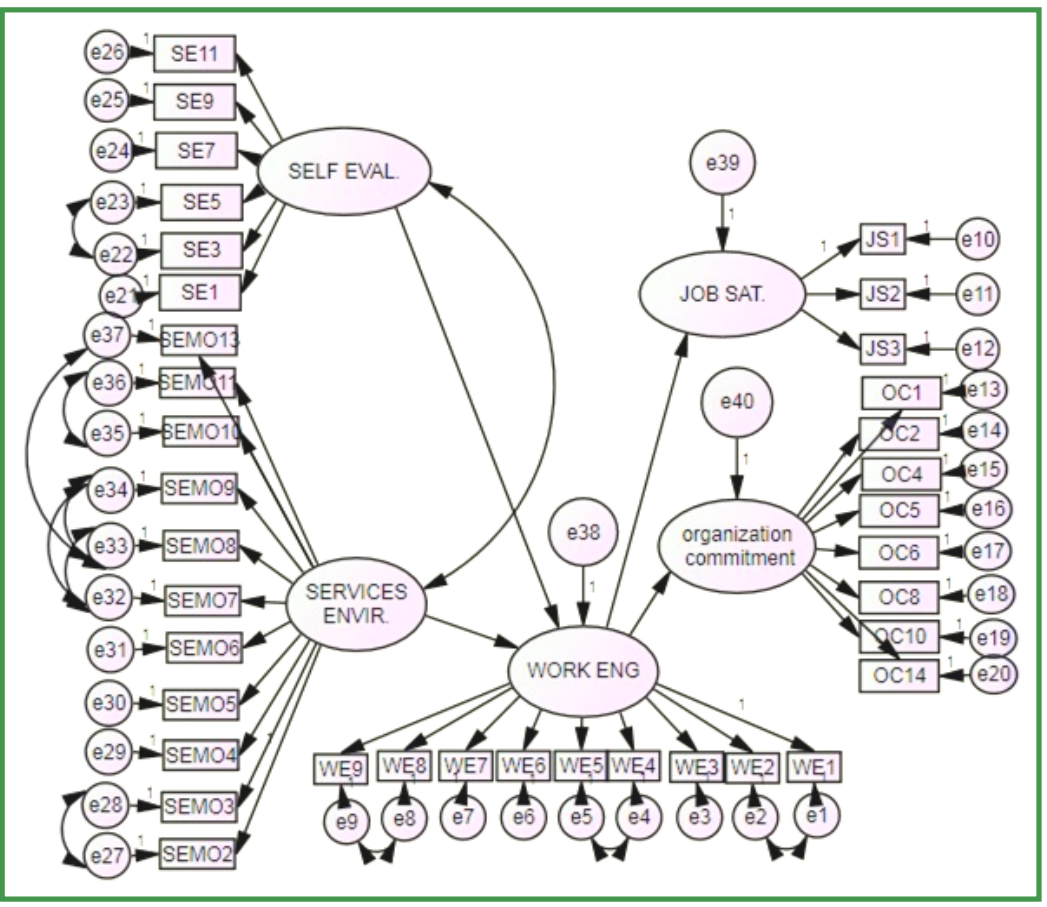

Figure 6. Structure Equation Model of Employee Engagement 
Figure 6 shows the structure equation model of determinants of employee engagement. Statistics derived from the figure indicates the acceptance of the model; with chi-square of 389.513 ( $\mathrm{df}=192$ ), a RMSEA of 0.045 , a PCLOSE of 0.540 , a CMIN/DF of 1.311, a GFI of 0.959 , a RMR of 0.092, AGFI of 0.923, and PGFI of 0.511. In the light of the above mentioned results, the model was acceptable. Figure 6 indicates that the path coefficients show the relationship among employee engagement, self -evaluation, psychological climate of organization and job satisfaction and organization commitment.

Table 4. Regression Analysis

\begin{tabular}{cccccc}
\hline \multicolumn{2}{c}{ Regression } & B-Value & Std. Error & $\mathrm{t}$ & $\mathrm{sig}$ \\
\hline S.E & E.E & .269 & .086 & 3.135 & .002 \\
S.E & E.E & .550 & .070 & 7.892 & .000 \\
E.E & J.S & .464 & .079 & 5.847 & .000 \\
E.E & O.C & .591 & .055 & 10.832 & .000 \\
\hline \multicolumn{5}{l}{ S.E= Self Evaluation, E.E= Employee Engagement, S.E=Services } \\
\multicolumn{5}{l}{ Environment, J.S=Job Satisfaction, O.C=Organization Commitment }
\end{tabular}

To check the impact on the engagement of employees of the banking sector by psychological climate and core self -evaluation the regression analysis is used. Table 3 shows the results of the analysis. Direct and significant relationship exists between psychological environment, self-evaluation and employee engagement. As per analysis model's fit is checked and found good. F test was used to check that fit of the model. The null hypothesis that is used to check the model fit is "model is not good fit". At $1 \%$ level of significance the value of $\mathrm{F}$ test (117.337) rejected the above mentioned null hypothesis, so it is concluded that model is good fit. 0.660 is the multiple correlations' coefficient for the study. Prediction quality of the measure can be measured by this (Laerd Statistics). Above value shows the good quality prediction. 0.436 is the $\mathrm{R}^{2}$ (Coefficient of determination) of the study. It also means that independent variables can elaborate $43.6 \%$ variation in the employee engagement. Due to the level of inclusion variables in the regression adjusted $\mathrm{R}^{2}$ is used to measure expected decline in the $\mathrm{R}^{2}$. Normally, generalizability is indicated by using adjusted $\mathrm{R}^{2}$. Greater generalizability can be achieved if the shrinkage between the adjusted $\mathrm{R}^{2}$ and $\mathrm{R}^{2}$ is low. In the current scenario shrinkage is very low i.e. 0.004 as adjusted $R^{2}$ value is 0.432 , in this way these results are generalizable to all of the population. Coefficients of independent variables are important in regression analysis hypothesis testing. Self-evaluation has significant and positive relationship with dependent variable employee engagement. This variables coefficient value is 0.269 and is significant at $1 \%$ level of significance that shows a positive impact on dependent variable. Thus in this way, first hypothesis of the study is supported i.e. employee engagement is positively correlated with variable which is independent, it also has its impact on employee engagement in both ways significantly and positively as it has coefficient value of 0.550 at $1 \%$ significance level. Self-evaluation, so this hypothesis is accepted. Psychological climate is the next.

So in this way it supports the $2^{\text {nd }}$ hypothesis i.e. Employee engagement is positively correlated with psychological environment of the organization. Employee engagement has positive impact on job satisfaction. 0.464 coefficient value is significant at significance level of $1 \%$. It means psychological environment has positive impact on employee engagement and in this way it also supports the third hypothesis of this research study and thus hypothesis is accepted. Fourth independent variable is organizational commitment of the employee it has coefficient value of 0.591 and it is significant at $1 \%$ significance level. It shows a positive impact on organizational commitment by employee engagement and in this way this fourth hypothesis is also accepted.

\section{Implications/Limitations/Suggestions}

Self-evaluation is one of the emotional states in the engagement of an employee that enhances his performance and ability to cope with the work. So, it requires attention to be selected as an important factor in the banking sector. It helps the employees to keep pace with work which enhances their performance that leads to better organization performance. On the other hand psychological behavior of an employee about the environment and climate in which he is working is also necessary to evaluate, rather than just evaluating the environment itself without knowing what an employee thinks about it [67]. Data is collected from the banking sector of Pakistan, though the sample size is low. Future recommendation in this regard is that sample size should be bigger and the data should also be gathered from other industrial sectors to reshape the antecedents of the employee engagement.

\section{Conclusions}

Self-evaluation the first independent variable of the study is in significant relationship with employee engagement, So if we consider this result, we have to look for the source that which study supports this result. In this scenario different studies that are conducted under hospitality settings, supports this phenomena that highly self-evaluated employees are more likely to engage in their work. Three psychological theories by Kahn also favor these results that when employee safety, availability while doing their jobs and psychological meaningfulness is provided to the employee, they automatically shows their engagement in work. So it is concluded that when people do have suitable environment, consider that their jobs are important and they have enough psychological resources they show more engagement to their jobs. So the employee that have the above three qualities of self-evaluation it can perform well. They set high objectives for their selves but they consider their jobs meaningless if they do not have any such accomplishments to achieve our objectives to meet. This indicates the optimism of an employee and whenever their 
goals and small objectives get achieved one by one they feel a sense of accomplishment. In this way they invest more power, engage their selves the best they can and extract the best out of the resources and time they work.

The psychological environment of the organization is also a significant predictor of employee engagement. Favorable and supportive work environment lessen the job demands, increase the job dedication and motivate them to do their jobs [68]. Previous Research on model JD-R supports the finding of this study $[69 ; 70 ; 8]$. So the conclusion is that management of the banking sector has to assure their employees that management is strongly committed about customer quality, in this way management should also provide good support to their employees, this will result into excellent engagement of employees in their work.

This study focused on the functional impact of job resources on employee engagement. However, in addition to the motivating process shown in the present study, the JD-R model also posits a health impairment process, in which some emotional, cognitive, and physical aspects of job or work environment (e.g., work overload, time pressure, and/or organizational rules of policies) may function as stressors that lead to health impairment. Therefore, because the present study did not include job demands as possible negative antecedents of employee engagement, it would be also worthwhile to investigate the effects of potential job demand variables as a negative predictor of employee engagement. For example, in the banking sector, emotionally challenging interactions with customers (i.e., high emotional job demands) has been recognized as an important factor for burnout and disengagement because it may exhaust service employees" psychological and/or physical resources. Given that employee engagement is on the decline and there is a deepening disengagement among employees today, additional research on job demands would provide a substantial contribution to hotel practitioners.

\section{REFERENCES}

[1] Koyuncu, M., Burke, R. J., \& Fiksenbaum, L. (2006). Work engagement among women managers and professionals in a Turkish bank: Potential antecedents and consequences. Equal Opportunities International, 25(4), 299-310.

[2] Bakker, A. B., \& Schaufeli, W. B. (2008). Positive organizational behavior: Engaged employees in flourishing organizations. Journal of Organizational Behavior, 29(2), $147-154$

[3] Khan, W, A (1990) Psychological conditions of personal engagement and disengagement and disengagement at work. Academy of Management Journal, 33(4), 692-724

[4] Macey, W. H., \& Schneider, B. (2008). The meaning of employee engagement. Industrial and organizational psychology, 1(1), 3-30.

[5] Sonnentag, S. (2003). Recovery, work engagement, and proactive behavior: a new look at the interface between nonwork and work. Journal of applied psychology, 88(3), 518.

[6] Goffman, E. (1961). Asylums: essays on the social situation of mental patients and other inmates.

[7] Xanthopoulou, D., Bakker, A. B., Demerouti, E., \& Schaufeli, W. B. (2007). The role of personal resources in the job demands-resources model. International Journal of Stress Management, 14(2), 121.

[8] Saks, A. M. (2006). Antecedents and consequences of employee engagement. Journal managerial psychology, 21(7), 600-619.

[9] Chen, Y., Ferris, D, L., Kwan, H, K., Zhou, M \& Hong, Y (2013) Self - Loves lost labor: A self - enhancement model of workplace incivility. Academy of Management Journal, 56(4), 1199-1219

[10] Baard, P. P., Deci, E. L., \& Ryan, R. M. (2004). Intrinsic Need Satisfaction: A Motivational Basis of Performance and Weil - Being in Two Work Settings1.Journal of Applied Social Psychology, 34(10), 2045-2068.

[11] Schaufeli, W. B., Bakker, A. B., \& Van Rhenen, W. (2009). How changes in job demands and resources predict burnout, work engagement, and sickness absenteeism. Journal of Organizational Behavior, 30(7), 893-917.

[12] Dutton, J. E., Roberts, L. M., \& Bednar, J. (2010). Pathways for positive identity construction at work: Four types of positive identity and the building of social resources. Academy of Management Review, 35(2), 265-293.

[13] Bakker, A. B., \& Demerouti, E. (2008). Towards a model of work engagement. Career development international, 13(3), 209-223.

[14] Kim, H. J., Shin, K. H., \& Swanger, N. (2009). Burnout and engagement: A comparative analysis using the Big Five personality dimensions. International Journal of Hospitality Management, 28(1), 96-104.

[15] Shuck, B., \& Reio, T. G. (2014). Employee engagement and well-being a moderation model and implications for practice. Journal of Leadership \& Organizational Studies, 21(1), $43-58$.

[16] Bakker, A. B. (2011). An evidence-based model of work engagement. Current Directions in Psychological Science, 20(4), 265-269.

[17] Maslach, C., \& Leiter, M. P. (2008). Early predictors of job burnout and engagement. Journal of applied psychology, 93(3), 498

[18] Galanakis, M., Moraitou, M., Garivaldis, F. J., \& Stalikas, A. (2009). Factorial structure and psychometric properties of the maslach burnout inventory (MBI) in Greek midwives. Europe's Journal of Psychology, 5(4), 52-70.

[19] Saks, A.M (2011) Work place spirituality and employee Engagement. Journal of Management, Spirituality \& Religion, 8(4), 317-340

[20] Schaufeli, W. B., Salanova, M., Gonzalez-Roma, V., \& Bakker, A. B. (2002). The measurement of engagement and burnout: A two simple confirmatory factor analytic approach. Journal of Happiness Studies, 3, 71-92.

[21] Gagné, M., \& Deci, E. L. (2005). Self - determination theory 
and work motivation. Journal of Organizational behavior, 26(4), 331-362.

[22] Kasser, T., \& Ryan, R. M. (1993). A dark side of the American dream: correlates of financial success as a central life aspiration. Journal of personality and social psychology, $65(2), 410$.

[23] Judge, T.A., Locke, E.A., Durham, C.C., \& Kluger, A.N (1998) Dispositional Effects on Job and Life Satisfaction: The Role of Core Evaluations. Journal of Applied Psychology, 83(1), 17-34

[24] Judge, T. A., \& Bono, J. E. (2001). Relationship of core self-evaluations traits-self-esteem, generalized self-efficacy, locus of control, and emotional stability - with job satisfaction and job performance: A meta-analysis. Journal of applied Psychology, 86(1), 80.

[25] Judge, T. A., Van Vianen, A. E., \& De Pater, I. E. (2004). Emotional stability, core self-evaluations, and job outcomes: A review of the evidence and an agenda for future research. Human performance, 17(3), 325-346.

[26] Judge, T. A., Locke, E. A., Durham, C. C., \& Kluger, A. N. (1998). Dispositional effects on job and life satisfaction: the role of core evaluations. Journal of applied psychology, 83(1), 17.

[27] Harter, S. (1993). Causes and consequences of low self-esteem in children and adolescents. In Self-esteem (pp. 87-116). Springer US.

[28] Judge, T. A., Erez, A., Bono, J. E., \& Thoresen, C. J. (2003). The core self - evaluations scale: Development of a measure. Personnel psychology, 56(2), 303-331.

[29] Lee, R. M. (2005). Resilience against discrimination: ethnic identity and other-group orientation as protective factors for Korean Americans. Journal of Counseling Psychology, 52(1), 36.

[30] Judge, T. A., Bono, J. E., Erez, A., \& Locke, E. A. (2005). Core self-evaluations and job and life satisfaction: the role of self-concordance and goal attainment. Journal of Applied Psychology, 90(2), 257.

[31] Koyuncu, M., Burke, R. J., \& Fiksenbaum, L. (2006). Work engagement among women managers and professionals in a Turkish bank: Potential antecedents and consequences. Equal Opportunities International, 25(4), 299-310.

[32] May, D.R., Gilson, R,L \& Harter, L.M.(2004) The psychological condition of meaningfulness safety and availability and engagement of the Human spirit at work. Journal of Occupational and Organizational Psychology 77, $11-37$

[33] Cullen, J. C., Silverstein, B. A., \& Foley, M. P. (2008). Linking biomechanical workload and organizational practices to burnout and satisfaction. Journal of Business and Psychology, 23(1-2), 63-71

[34] Margolis, J. D., \& Molinsky, A. (2008). Navigating the bind of necessary evils: Psychological engagement and the production of interpersonally sensitive behavior. Academy of Management Journal, 51(5), 847-872.

[35] Carr, J. Z., Schmidt, A. M., Ford, J. K., \& DeShon, R. P. (2003). Climate perceptions matter: a meta-analytic path analysis relating molar climate, cognitive and affective states, and individual level work outcomes. Journal of Applied Psychology, 88(4), 605.

[36] Baltes, B. B., Zhdanova, L. S., \& Parker, C. P. (2009). Psychological climate: A comparison of organizational and individual level referents. Human Relations, 62(5), 669-700.

[37] James,L.R., Hater,J.J.,Gent,M.j \& Bruni, J.R (1978) Psychological climate: implications from cognitive social learning theory and interactional psychology. Personnel psychology, 31

[38] Bakker, A. B., Schaufeli, W. B., Leiter, M. P., \& Taris, T. W. (2008). Work engagement: An emerging concept in occupational health psychology. Work \& Stress, 22(3), $187-200$

[39] Reizer, A (2014) Influence of Employees' Attachment Styles on Their Life Satisfaction as Mediated by Job Satisfaction and Burnout. The Journal of Psychology: Interdisciplinary and Applied, 1-22

[40] Matzler, K., \& Renzl, B. (2006). The relationship between interpersonal trust, employee satisfaction, and employee loyalty. Total quality management and business excellence, 17(10), 1261-1271.

[41] Alarcon, M.G \& Lyone, J.B (2011) The Relationship of Engagement and Job Satisfaction in Working Samples. The Journal of Psychology: Interdisciplinary and Applied, 145(5), 463-480

[42] Herzberg, F., B. Mausner, and B. B. Snyderman (1959). The Motivation to Work (2nd ed). New York: Wiley.

[43] Hertzberg, F., Mausner, B., \& Snyderman, B. (1959). The motivation to work. New York, itd: Wiley.

[44] Jones, R. J., \& Sloane, P. J. (2007). Low pay, higher pay and job satisfaction in Wales. Spatial Economic Analysis, 2(2), 197-214.

[45] Hytti, U., Kautonen, T., \& Akola, E. (2013). Determinants of job satisfaction for salaried and self-employed professionals in Finland. The International Journal of Human Resource Management, 24(10), 2034-2053.

[46] Wefald, A. J., \& Downey, R. G. (2009). Construct dimensionality of engagement and its relation with satisfaction. The Journal of Psychology,143(1), 91-112

[47] Srivastava, P., \& Bhatnagar, J. (2008). Talent acquisition due diligence leading to high employee engagement: case of Motorola India MDB. Industrial and Commercial Training, 40(5), 253-260.

[48] Allen, N. J., \& Meyer, J. P. (1996). Affective, continuance, and normative commitment to the organization: An examination of construct validity. Journal of vocational behavior, 49(3), 252-276.

[49] Mowday, R. T., Steers, R. M., \& Porter, L. W. (1979). The measurement of organizational commitment. Journal of Vocational Behavior, 14, 224-247.

[50] Steers, R. M. (1977). Antecedents and outcomes of Organizational commitment. Administrative science quarterly, 46-56.

[51] Meyer, J.P\& Allen, N.J(1991) A three component conceptualization of organizational commitment. Human resource management review, 1(1),61-89 
[52] Eisenberger, R., Huntington, R. H., \& Sowa, S. (1986). Perceived Organisational Support. Journal of Applied Psychology, 71(31).

[53] Van den Broeck, A., De Cuyper, N., De Witte, H., \& Vansteenkiste, M. (2010). Not all job demands are equal: Differentiating job hindrances and job challenges in the Job Demands-Resources model. European Journal of Work and Organizational Psychology, 19(6), 735-759.

[54] Homans, G. C. (1958). Social behavior as exchange. American journal of sociology, 597-606.

[55] Passmore, W.A \& Khalsa,G.S (1993) The contributions of eric trist to the social engagement of social science. academy of management review, 18(3),546-569

[56] Schaufeli, W. B., \& Bakker, A. B. (2004). Job demands, job resources, and their relationship with burnout and engagement: A multi - sample study. Journal of organizational Behavior, 25(3), 293-315.

[57] Houkes, I., Janssen, P. P., de Jonge, J., \& Nijhuis, F. J. (2001). Specific relationships between work characteristics and intrinsic work motivation, burnout and turnover intention: A multi-sample analysis. European Journal of Work and Organizational Psychology, 10(1), 1-23.

[58] Meyer, J.P\& Allen, N.J(1991) A three component conceptualization of organizational commitment. Human resource management review, 1(1),61-89

[59] Purang, P. (2008). Dimensions of HRD Climate Enhancing Organisational Commitment in Indian Organisations. Indian Journal of Industrial Relations, 528-546.

[60] Albrech, S.L(2012) The influence of job, team and organizational level resources on employee well-being, engagement, commitment and extra-role performance Test of a model. International Journal of Manpower, 33 (7), $840-853$

[61] Hakanen, J. J., Bakker, A. B., \& Schaufeli, W. B. (2006).
Burnout and work engagement among teachers. Journal of school psychology, 43(6), 495-513.

[62] Maslach, C., Schaufeli, W. B., \& Leiter, M. P. (2001). Job burnout. Annual review of psychology, 52(1), 397-422.

[63] Schaufeli, W. B., \& Bakker, A. B. (2003). Utrecht work engagement scale: Preliminary manual. Occupational Health Psychology Unit, Utrecht University, Utrecht.

[64] Judge, T. A., Erez, A., Bono, J. E., \& Thoresen, C. J. (2003). The core self - evaluations scale: Development of a measure. Personnel psychology, 56(2), 303-331.

[65] Amenumey, E. K., \& Lockwood, A. (2008). Psychological climate and psychological empowerment: an exploration in a luxury UK hotel group. Tourism and Hospitality Research, $8(4), 265-281$.

[66] Cammann, C., Fichman, M., Jenkins, D., \& Klesh, J. (1979). The Michigan organizational assessment questionnaire. Unpublished manuscript, University of Michigan, Ann Arbor.

[67] Brown, S.P \& Leigh,T.W(1996) A New Look at Psychological Climate and Its Relationship to Job Involvement, Effort, and Performance. Journal of Applied Psychology, 81(4), 358-368

[68] Demerouti, E., Bakker, A. B., De Jonge, J., Janssen, P. P., \& Schaufeli, W. B. (2001). Burnout and engagement at work as a function of demands and control. Scandinavian journal of work, environment \& health, 279-286.

[69] Hakanen, J. J., Bakker, A. B., \& Schaufeli, W. B. (2006). Burnout and work engagement among teachers. Journal of school psychology, 43(6), 495-513.

[70] Xanthopoulou, D., Baker, A. B., Heuven, E., Demerouti, E., \& Schaufeli, W. B. (2008). Working in the sky: a diary study on work engagement among flight attendants. Journal of Occupational Health Psychology, 13(4), 345 